\title{
MEMORIES FROM THE MARGINS: STORIES AND IMAGES OF URBAN HOMELESSNESS
}

\author{
CYNTHIA J. MiLleR \\ Emerson College, U.S.A.
}

\begin{abstract}
Among any city's most wounded bodies and minds are the homeless - individuals who live on the streets, without any formal claim to place. For many of these individuals, the vessels of historical memory are not museums, or classrooms, or library archives, but parks, alleyways, and subway stations. As the numbers of homeless individuals increase dramatically each year, their social, physical, and psychological trauma increasingly characterizes urban life, even as their experiences fall to the margins of the city's history and future. In response, this paper explores the merging of homeless histories with public history, through two interlocking projects carried out in Boston, Massachusetts "Histories and Homelessness," a community-based life-writing project, and "Images from the Streets," a disposable-camera photography project - outreach and education projects, in which all participants are among the unsheltered homeless who spend their nights on heating grates, under highways, and in ATM kiosks. Together, these projects begin to map and make visible the landscape and memories of homelessness, as they are written and photographed by its inhabitants, and firmly situate these histories within the wider community. Recovering the personal and interpretive histories of homeless individuals, so intimately tied to "place," creates a powerful strategy for expanding the history of the community to include voices and visions often excluded or left at the margins.
\end{abstract}

Keywords: cultural studies, urban life, personal and public history, historical memory, marginality, photography

and the way $\mathrm{i}$ see it this place is mine and these streets belong to me because $\mathrm{i}$ live here i'm not just passing by this is where i spend my day and my night this is where $\mathrm{i}$ hang my hat or lack thereof this is where i sleep and drink and work and dine and YOU are just passing by, coming into my home and passing me by with downcast eyes one part sympathy two parts hate as you turn your face away. i don't barge through your front door and disrespect you like this i don't do any of that. (Rachel) 
We often think of homeless individuals as somehow "placeless." They are more mobile - their geography of identification appears to be fluid, rather than fixed. They seem to lack the most common terrain of identity laid claim to by the domiciled population - a stable location from which they can draw (and onto which they can project) their preferences, values, and idiosyncrasies. The key descriptor of their identities is not an individual one of personal attributes, but a collective one of social condition. They are "the homeless," and invisibility is a valuable life skill more often than it is an obstacle. Understanding the role of "place," then, in the lives of the homeless - and the role of the homeless in the life and history of a "place" - can be difficult. This is especially true in the case of the unsheltered homeless - those individuals and families who do not spend their nights in shelters, but in cars, in ATM kiosks, in alleys, and beneath overpasses. Investigating the links between environmental justice and the homeless sets the stage for them to be recognized as a visible and significant part of the life of a community, and at the same time asks that they reflect on their environments in ways which construct them as subjects in relation to their surroundings, rather than as objects in the surroundings of others.

This essay presents an examination of what one homeless individual referred to as "memories of no place" — narratives of lives lived on the streets, where personal history becomes public, and public history becomes personal. It explores links between self and surroundings among the unsheltered homeless, through words and images created by homeless individuals, themselves. The "words" are drawn from a community-based life-writing project, in which all individuals who participate are homeless. These writings, or in some cases, dictations, are narrated, illustrated and often enacted by their writers, to build a complex picture of how their identities have been formed and influenced by where and how they have lived - "re-placing" the writers' lives within the community. The "images" are drawn from "Images from the Streets," a photography project showcasing the landscape of homelessness, as it is photographed by its inhabitants. The project explores the ways in which the photographers' work becomes more than simply the products of creative expression, examining how the act of rendering that landscape visible can foster social change.

The writings and photographs that emerged from the projects examined here serve as tools to affirm and give voice to individuals' knowledge, perspectives, relationships, and stories, and to add depth and dimension to those place-based identities through which they are so often limited. Taken together, they offer homeless individuals opportunities to engage with their lives and surroundings in a range of ways that illustrate the intricate interweaving of place with the identities of the homeless, and demonstrate that they are not "just passing by." 


\section{A Community of Injustice}

As an embedded community, homeless individuals reside in sites of multiple injustices. They are generally the most disadvantaged of the extremely poor (see Rossi). Whether living on the streets by choice, or due to soaring housing costs, low wages, inadequate healthcare, or ever-tightening limits on public assistance programs, homeless people are generally bracketed apart from the wider community's concerns for social and environmental justice. In fact, many relate feelings of being an integral part of the general population's perceived injustices. As one homeless man related: "Hell, guys like me? I'm their pollution." Anthropologist Joanne Passaro explains that Americans have a cultural tendency to place blame on the homeless (in particular, men), and to see them as shouldering the sole responsibility for their circumstances - as having failed in the performance of their designated social roles. (36) This perception of "unworthiness" eases the complicated feelings and difficult questions which confront the general population about homelessness, and allows homeless individuals, and the injustices they face, to be dismissed, either falling well outside the realm of consideration or being added to the bottom of that list of ills plaguing the community.

An inescapable image of extreme poverty is linked with Passaro's notion of "unworthiness" in the generalized image of homelessness within a community. Commonly reported stereotypes of homelessness are most often of people loitering outside shelters, panhandling on corners and in bus stations, and sleeping on park benches; and since the people who live on the streets - the unsheltered homeless - are the most visible, they tend to be the most closely associated with homelessness. As writer and activist Steve Vanderstaay explains:

Homeless people on the street are also the most feared and least identified with: people who die ignominious deaths in trash compactors, who freeze outside the doors of hospitals, and who have been burned alive while sleeping on park benches. They are the most hated of homeless people; loathed for their destitution, their apparent inability to provide for themselves, and for the conflicting array of emotions they evoke in passersby (4).

Many individuals, however, remain unsheltered, facing these severe social and environmental conditions, as a result of one of the most significant injustices facing the homeless community: the shelter system. There is an ever-growing shortage of beds in city shelters - the United States Conference of Mayors reported an average 13\% increase in demand for emergency shelter in all major cities for the winter of 2010 , with $70 \%$ of cities surveyed, including Boston, turning away as much as one-third of requests for shelter from individuals, and 
only slightly fewer rejections of requests from homeless families. (24)

Even when there are beds available, however, many homeless individuals find remaining on the streets preferable to conditions in city shelters. As one homeless man, Warren, relates:

I was sick of being a second-class citizen and a pariah. I was sick of being herded from shelter to shelter among a throng of human cattle. And I was sick of watching people slowly dying, trapped in a morbid cycle of shelters, day labors, and liquor stores.

Warren's comments mirror the sentiments and stories of many people describing their reasons for choosing life on the streets. For some, it is a marker of pride and autonomy; for others, it represents another aspect of their individuality connection and attachment to place. As Joe, a man in his 30s who had been living in the alley next to a downtown church for much of the past three years, explained during a writing session:

I don't have much that's mine. Just this crap here I keep with me. And this alley I'm writin' about. This is mine. Ain't nobody sleeps here but me. Ain't nobody pisses here but me. Nobody filthyin' up the place, either, 'cept those damn drunk kids who got no respect for nobody or nothin'. And the church, of course, when they trot out their trash once a week to keep me company. And there's been some stuff worth sharin' my alley with in there, too. Not so bad.

Joe's explanation begins to illustrate how the status of being homeless brings greater complexity to Wendell Berry's notion that in order to know who we are, we must know where we are. (7) Our identity, he writes, is defined to a large degree by our sense of place, our sense of home, and by the traits of our environment. The writers and photographers I discuss here see themselves, and are seen, almost solely through the lens of place: the guy under the bench near the " $T$ ", the woman on the heating grate, the old man in the alley. The challenge in their writings and images is to draw out the stories which animate those relationships with place in ways that retrieve the individual, and his or her thoughts, feelings, and actions, from invisibility.

This exploration of the intersection of personal and public history among Boston's homeless originated with a multi-year project on oral histories and life-writing among individuals whose voices are often at the margins of the history of place and community. The project began somewhat organically, the result of two informal writing groups held at day programs - one in an outreach facility, the other, in the basement of a downtown church with a meal program. The writers' groups met weekly for just over two years, sometimes with only one or two writers, other times with seven or eight, and additional facilitators. Writing sessions might last for most of the morning, or for only half an hour, as 
the writers' needs, abilities, and patience dictated. While the 32 individuals who contributed to this project represent only one half of one percent of Boston's documented homeless, their narratives represent roughly $10 \%$ (in winter) of those homeless who choose or are forced to find accommodations outside the shelter system. Demographically, they roughly mirror the city's larger demographics of homelessness, with four times as many men as women, and in terms of race, slightly under 50\% Caucasian, about 36\% African-American, and $12 \%$ Hispanic. $^{1}$

\section{Images and Identity}

Over time, other facets were added to the research, including "Images from the Streets," a disposable camera project designed to create a space for homeless individuals to explore visual narrative served to highlight personal assets, which might then, in turn, be used to nurture a stronger sense of self and foster new connections within the community. The photographers were asked to record images of significant people, places, or occurrences in their worlds, over the course of a week. The resulting sets of photographs expressed their shared and yet unique experiences, angers, hopes, and visions.

The group of photographers was comprised of five men and one woman - Deb, Tommy, Sly, Billy, George, and Ed - all of whom had been living on the streets for varying lengths of time. All were familiar with the use of the camera, and required no coaching, though at the outset, all were concerned about meeting our expectations, in terms of the content of the photographs. However, when the project was reframed as "a day in the life" - a story in pictures about what mattered to them most - each seemed to leave with a strong sense of what to include in a series of pictures that would reflect their identities. Deb, the only female of the group, later described embarking on the experience as being "on a mission. I was going out to take pictures of what I see that you don't ... But I ended up taking pictures of what I see that you don't think I see."

What did the photographers see and record? The images captured on film were highly varied, and reflected the perspectives and individualities of the photographers. The subjects, however, may be roughly separated into three broad categories: images of affiliation, images for education, and images of assertion.

Images of affiliation featured relationships and personalities as their focal point. Individuals with whom the photographers held close relationships or shared common space were the central concern of a large number of

\footnotetext{
${ }^{1}$ Although at city, state, and national levels, children are the fastest increasing homeless population, there is no "under-18" representation in this project.
} 
photographs. In general, these were homeless people. The emphasis of the photographs, however, was not that they were homeless, but that they were people. Solemn faces, laughing faces, thoughtful faces, and angry faces - caught in private moments that would now become public. Billy, whose images were nearly all of this type, described his portfolio as a kind of "family album," and paused at each one to relate stories of first meetings, shared experiences, and separations. Images of outreach workers in unguarded moments - caught unaware and vulnerable, or stepping out of their roles and "mugging" for the camera - also figured significantly in this category. These uncharacteristic displays seemed to deliberately subvert the "typical" relationships that existed between the photographers and volunteers, priests, and activists, and were cited by photographers as illustrations of their belief in a basic, shared humanity and sameness.

Scenes of individuals and places that typified the homeless condition dominated the category of images for education. Images of overburdened shopping carts, laundry hanging on stairway handrails, human forms barely visible under piles of newspaper and clothing, and heating grates puffing clouds of warm steam all spoke to the day-to-day experiences of homelessness, conveying themes of invisibility, uncertainty, and hopelessness. One particularly notable photograph pictured a long line of legs and feet, awaiting the opening of a soup kitchen for their evening meal. Sly, the author of the image, described it as summing up for him "the endlessness and facelessness of waiting for the basics."

It was here that that the significance of "place" was communicated most clearly. The places represented in the photographers' images were used to literally locate homelessness - places where those without homes lived, and sometimes died. With these photographs, the contributors mapped out the landscape of homelessness in the downtown area, drawing attention to the underpasses, alleys, and parks where they spent their days and nights, the impoverished tenement houses from which some of them had come, and the "mainstream" spaces, such as the public library or ATM kiosks, that they appropriated for shelter or rest. Each of these images of place acknowledged the sharp divide between the domiciled population and those on the street partitioning the downtown area into "our places; where we belong" and "your places; where we squat and trespass and are made unwelcome."

But then, there were images of affirmation, which stood in stark contrast to these desolate scenes of homelessness. These photographs were not about the alienation or limitations of being homeless, but rather, about the strength of vision and potential felt by their authors. The photographs categorized here included scenes of natural beauty, such as a frame full of flowers or swans floating in a pond; dawn just beginning to light the sky, witnessed from the vestibule of a church; self-conscious artistry of perspective, light, and color, intentionally illustrating the creative abilities of the photographer - shots taken 
as an affirmation of talent and potential. Tommy, who also paints, explained that he had chosen subjects and techniques that would demonstrate both his talent and his hope: "Everyone looks at homeless people and thinks we have nothing to offer. They're surprised that I paint, and I think this [photograph] will surprise them too. When I took this, I wanted to show them that I can do something worth looking at."

The commentary and categorizations here actively demonstrate the reflection on experience, relationships, self, and surroundings, prompted by the process of photography. This informal analytical component was the product of several casual meetings, where the photographers viewed and selected the photographs to be displayed and crafted their titles and narratives, and also later, during the exhibition itself. While no formal, structured critical analysis of the images was carried out, these informal categorizations and comments reinforce the photographs' value as tools for drawing attention to the photographers' worlds and values. They are a call to "look!" -and not simply "look at me," but "look at me see." (Chalfen 2-33) They summon the observer to "Look at the meaning in my world."

\section{Images and Empowerment}

Photography and video projects of this sort have been receiving greater attention over the past several decades, as vehicles for empowerment, media for the expression of identity, and tools in the valorization of experiences. Sometimes framed as "documentary photography," "photoethnography," "participatory video," or as "shooting back," these projects take as their focus the "insider's" perspective, seeking to explore and understand individuals' worlds through their eyes. While significant distinction can be made between still versus moving media, particularly in terms of the processes of representation and interpretation (see Barthes 1981), the common thread among these endeavors is their attempt to find "another way of telling" (see Berger 1982) - to create space for visual narrative among previously silenced, underrepresented, and marginalized groups ${ }^{1}$. Sociologists, anthropologists, therapists, and others working in visual studies have utilized participatory visual methods with such diverse groups as

\footnotetext{
${ }^{1}$ Among the earliest and most important of these projects is the film series and volume Through Navajo Eyes (1972, reprint 1997), by Sol Worth and John Adair, in which the authors used filmmaking as a medium for attempting to explore how six Navajo men understood and structured their worlds. Using still photography, rather than video, as a medium, Wendy Ewald's project, Portraits and Dreams: Photographs and Stories by the Children of the Appalachias (1975), narrates the everyday lives of Appalachian children in their own words and images, and is frequently cited as one of the foundational efforts in the use of photography with individuals formerly framed as "subjects."
} 
children, the elderly, the terminally ill, and a range of cultural groups (Entin 1980; White 2003; Gauntlett 1997; Hubbard 1991, 1994). These participatory visual methods, while offering entrée to stories and perspectives typically unavailable to researchers, also offer opportunities for awareness-raising and social change. ${ }^{1}$

The power of the photograph lies in its abilities to reveal and reflect - to create dialogue between individuals and social worlds. The act of photographing one's world requires reflection on experiences, values, and identity in order to determine what one wishes to communicate, and what images will constitute that message. The product, a photograph, then continues the reflective process through acceptance or rejection as an apt representation, contextual narration, reception by its audience, and the dialogue it encourages. The photograph is a call to look. It captures a glimpse from a unique subjectivity, of a moment that will never occur again - an occurrence that may never again be observed in the same way - or as Roland Barthes suggests, "In the Photograph, the event is never transcended for the sake of something else ... ." (4) Through the photographs in "Images from the Streets," the worlds and visions of the project's homeless photographers call to not be overlooked. The project asks both its contributors and audiences to view the experiences and perspectives communicated through the images as inherently valuable - not to be passed over or deemed insignificant in the service of limiting stereotypes.

\section{Worlds and Words}

The writers' group also narrated worlds and visions that could not be overlooked or deemed insignificant. 40-year-old Dragon, who had been living on the streets for the 15 years since his discharge from military service, took me on his own version of a "walking tour" of downtown Boston to illustrate a writing he had just finished, linking alleys and corners to specific seasons and years and events of his life on the street, tying many of them to life lessons learned, or the rise and fall of his personal characteristics and beliefs. In talking about his winter at the Ruggles T-stop he related that:

Now that place there ... turns you as black as shit. Not that I ain't already black ... but I mean, on the inside ... dark ... hard as that wall over there, and just as pissed on ... and you turn into the place ... or it turns into you ... I ain't too sure how that shit goes, but it's still in me ... winter ... back in '97 ... the trains

\footnotetext{
${ }^{1}$ As exemplified by the Sundance award-winning documentary, "Born into Brothels" (ThinkFilm 2004) and its non-profit off-shoot, Kids with Cameras. With an eye toward creating more direct social change using participatory visual methods, the recent Photovoice concept (Wang and Burris, 1994) has enabled individuals to chronicle their experiences and enact change within their communities.
} 
screechin' on the rails ... the stench of piss and cigarettes ... pigeon shit ... it's all hangin' there in me ... black ...

While individuals on the streets may live without the formal claim to place that inheres in the mainstream population, many of those with whom I worked, like Dragon, used their surroundings, no matter how temporary, as tools to ground their identities. As one woman suggested "... maybe we pay closer attention to where we are, 'cause that's now, and that's all we are." That "closer attention" made itself apparent time after time in the writing groups' narratives. After a while, it became clear that whether one wanted to understand life histories or map death sites; find a soup kitchen or hide from outreach; nearly all knowledge derived from being "place-less" was, in fact, based in place.

Billy, who lives on the edge of Boston Common, has been hospitalized twice as a result of toxic substances poured over the contents of dumpsters by local restaurant staff, in an effort to discourage homeless individuals from looking there for food. In an essay about his decreasing sense of safety on the streets, Billy wrote angrily about "dumpster diving" - scavenging for food in restaurant dumpsters:

Diving. You think it's my recreation, but it's my livelihood. You think it's my hobby, but it's my survival. You. You throw out enough food everyday to feed me and all my boys and not even miss it. Isn't it enough that I demean myself, take myself down to your dumpster and dive in? I don't do spare changin'. I don't beg. I just eat your food when you're done with it.But no, that ain't enough for you, is it? You go and pour out bleach over all that God given food, just to make sure I can't eat. Just to make sure that Billy don't scare away your fancy customers. Just to make sure they don't have to eat in the same place as me. Or maybe you just want me to die.

Revitalization efforts in the neighborhoods around Boston Common continue to push individuals living on the streets further away from developing areas, and expanding surveillance and control around exclusive hotels, restaurants, offices, and condominiums, rising up in sharp contrast to homeless life on the streets. As a result, homeless people are increasingly moved away from the safety of areas in close proximity to the Common, and further into locations where their physical safety is at greater risk, and their senses of being "in place" are significantly diminished. As one woman related:

Okay, so it probably didn't do much for business when I'd sneak under those little heat lamps out front for a couple minutes. But it was the dead of winter, and oh, were they warm! Now I don't even stop before getting moved along, further down into Chinatown, where I know I don't belong. I get lost in there. There are too many streets I don't know, people I don't know, screaming at me 
things I don't understand. I hate to admit this, especially at my age, but I get confused, and a little scared. (Bettey, age 57)

In order to better understand those things that contributed to the writers' feelings of being "in place" and the impact of events which diminish that sense, we initially approached several broad questions about their relationship to place: How did memories and experiences of earlier "places" - their environment, in its broadest sense - affect or shape writers' present day attitudes, values, fears, and relationships with place? In what places did they feel most "at home," most like "themselves," in contrast to Bettey's Chinatown experiences? How had these places changed during the course of their homelessness? How had changes in their surroundings changed the quality of their lives?

The value of these initial questions is that the responses continued to illustrate some of the ways in which homeless identities are firmly rooted in place - or in many places; how critical "place" is to homeless identity, and how damaging it becomes when that sense of being "in place" is weakened or taken away. There is, in fact, a landscape of homelessness. In Grand Central Winter, Lee Stringer writes of the homeless terrain: "Like Ellison's Invisible Man, we had receded into that part of the landscape that refused to support the American Dream" (57). Over and over, narratives found in the group's life-writings point to the significance of surroundings in the lives of the unsheltered homeless. Not simply in terms of exposure to the elements, but in terms of the creation and maintenance of a sense of self, illustrating that marginalization of the homeless can occur on levels other than economic or social. Members of the writing group indicated that they often experience their environments more intimately, draw different levels of knowledge from them, and have more pronounced feelings of alienation - at least from that part of the environment to which the domiciled population has laid claim:

some say it's the daffodil that marks the spring, others claim it's a rodent but the only problem is they've got the wrong rodent pinned. they all wait around for this ground-hog to tell them when things are going to be warming up but in reality it's the rat. when the rat shows its face after a cold winter it means spring is here. Spring isn't pretty flowers and april showers, spring is rats and heaps of trash, and right after spring comes summer and a sizzling heap of new problems and big shots telling you where to go. (Rachel)

As Rachel's essay illustrates, experiences of place include not only perceptions and valuations of particular sites or surroundings, but also feelings about places and what happens in them. Significant environments may change over the lifecourse as needs, interests, and concerns change, but positive or negative emotional associations with place often remain, helping make them the unique individuals they have become. 


\section{Lives in "Place"}

In order to expand on the experiences and knowledge derived from life on the streets, and learn more about the trajectory of social and environmental injustice in the lives of the homeless, participants were introduced to the idea of "place biographies" and asked to think and describe a significant place over time, from their first experience to the present. This approach not only served to document the continuing marginalization and degradation of the areas frequented by the homeless, but also served to create an environmental thread through the places and events of the participants' lives, rooting them "in place" in very observable ways.

The focus of this approach is to choose a particular site - a building, waterfront, woods, alley - and follow it through time, paying attention to the ways in which its appearance, uses, and what was expected of it, as well as the people and activities which animated it, changed over time, loosely following a model like that offered by John Brinckerhoff Jackson in "The Westward Moving House," in which he traces several generations of a family through the houses in which they lived, looking at the ways the house serves as an artifact that both reflects and shapes the culture and psychology of the family. This sort of historical study, when used as an historical study, can lend itself to a relatively impersonal perspective on "place." However, when modified so as to encompass not all of the history of a site, but only an individual's experiences of it (and their handed-down knowledge of any informal lore), the place biography becomes a powerful tool for situating knowledge and experience in specific locations. When narratives are controlled for variables such as gender or age, landscape histories can also give clues to how such variables impact the experience of particular sites, for example, in terms of safety or accessibility. Members of the writers' group provided place biographies that have proven useful and interesting, not only for their "subaltern" qualities, but for their indication of sites significant to the lives and experiences of the homeless.

When asked to choose a location and write this sort of personal landscape history or place biography, nearly one third of the writers or contributors chose the alley behind the Boston Public Library as their focus. An essay by Joanna, a 41-year-old woman who has been on and off the streets for four years, illustrates:

Four years ago, the street right behind the BPL didn't see much traffic. Not from us, and not from anyone else. It was quiet ... peaceful ... a cut-through, I think, more than anything, and maybe a place to park without a resident sticker and not get caught. But with all that quiet, and those big heating grates from the 
library, it was a good place for some of us to sleep, you know? And not a lot of people knew about it. But then the condos came to the block alongside the library - big, bright, tall and expensive. The whole neighborhood changed. They didn't want us homeless people ruining their view of the architecture, you know ...

Rory's narrative continues the history:

about a year ago, they banned the boys with the Outreach Van from bringing blankets and socks there on their rounds - thinking that would move us along. Now the place is crowded at night — so crowded you don't feel safe anymore. Nobody wants the vans pestering and checking up. Vehicles on the street where we're tryin' to sleep ... headlights ... not knowin' who they are until they're right on top of us ...We don't want their "outreach" — we want to be left alone and be safe. And everybody's fighting for the grates ... After this winter, I'm movin' on — outta the high-rent district.

Joanna's and Rory's writings along with several others, speak to not only the history of the site as they have lived it, but to power, fear, economic development, mainstream attitudes toward homelessness, and obstacles to the services which try to address it.

Often, the writers' historical narratives served to highlight significant environmental issues in the homeless community, such as demolition, gentrification, the many lives of squatter space, and exposure to the elements. Rodney wrote in elegant detail of winter days spent sledding down the mountainous-seeming hill of the Boston Common, mounding it up into bumps for an extra thrill, and then burying friends in the snow until they shook themselves free. As he wrote further, this memory became intricately interwoven with a recent adult memory of finding a homeless friend buried in snow, frozen to death after a night spent without shelter. "I used to love winter. Tore outside with the very first flake. Now, winter is the enemy. It kills. One dead here, another there, little bits of death marking places I sleep and eat and sit ... that's a little bit of my own death, right there."

As Rodney read his essay aloud for the group, each member echoed his sadness and related similar experiences - or realized they had known some of the same people - not through the identification of name, but by death site. When talk wore down, they decided that in the following session, they would all write narratives of a place where someone they knew had died. Soon, most were morbidly joking about "the dead zone session" - black humor that linked them to each other in a way they hadn't been before. 


\section{From Creativity to Activism}

That early, unanticipated teamwork was only the beginning of the collaboration and community fostered by the act of life-writing. While the life-writings created by the group have been deeply empowering on an individual basis, they have taken on far more active lives and lessons for the writers and a much wider community. Our weekly sessions have evolved from simply quiet time to sit and write with an available facilitator, to time when writings - and struggles with writing - are shared, creating a community of shared stories and experiences. It all began one day when Walter, a man in his late $50 \mathrm{~s}$, read a piece he had just completed about his season under the highway overpass, getting sicker weekly from the exhaust fumes of cars passing overhead. The others listened to Walter's words quietly, at first, and then some began to interject questions, reminiscences, and similarities. Another writer quickly sketched Walter's scene as it was evoked for him, and at the end of half an hour, we were planning the creation of an anthology - a collection of stories, themes, and pictures that would express the shared and yet unique histories, angers, hopes, and visions of the writers.

These collaborations have taken other paths, as well, and significantly altered the stage on which the struggles of homelessness are acted out. At the completion of the photography project, "Images from the Streets" was placed on exhibition at my university as a kick-off event for a week of awareness-raising events focused on hunger, homelessness, and housing. The 50 enlarged, matted photographs chosen by the contributors for display were hung gallery-style along the walls and columns of the reception hall-turned-gallery. The event was open to the community-at-large, and featured a reception to honor and meet the photographers. Members of the university community attended the opening, as did the photographers' friends and supporters, and staff from homeless outreach programs in the city's downtown area. Throughout the day, the photographers narrated the stories of their pictures and contextualized them in terms of their lives on the streets.

The exhibition then moved to residence at two area churches - one in Boston, the other in the suburbs, in order to give wider access and recognition to the photographs. The images were then retired. In a significant demonstration of sustainability, a second, expanded exhibition, conceived and coordinated by the original contributors was organized on the anniversary of "Images from the Streets," in order to provide a vehicle for other homeless individuals to tell the stories of their lives in pictures.

What had started as a spontaneous "in their own voices; from their own visions" initiative developed into something much more. The contributors were eager to hold an active role and a defining voice in selecting and contextualizing their photographs, and narrated their images with pride, rather deflecting the focus away from themselves. In the months that followed, two of the 
photographers gave talks to classes and community groups about their art, and the value of promoting creative expression among the disenfranchised. Tommy explained during one of these talks:

As long as I paint or take pictures, I know there's more to me than just being some guy who lives on a bench in the park. I know there's something about me to notice ... something to pull me up ... something I know about myself because I can look at it on the lousy days and remind myself what I've done. How can anybody say that because I'm homeless I shouldn't have that? That if it doesn't get me bus fare or a burger, it's a waste of time? That's like saying what's inside me is a waste of time.

It was that belief that led the photo-artists of "Images from the Streets" to take up the project again, on their own, to share with others, with the support of Neighborhood Action. Several new photographers joined the exhibition, mentored by the original contributors. Those of us who had been involved in the original exhibition were invited to the second opening as a surprise. This demonstration of sustainability - initiative, planning, mentoring, and execution is, perhaps, the project's most significant contribution toward social change.

Several of the photographers and writers involved in the two projects have been asked to speak to community groups and classes about their works, and lives and landscape of the homeless community, adding faces and humanity to the wider community's concept of homelessness. Additionally, Doris, a homeless woman with community theater background, has turned her writings into several one-act plays, which she and other homeless actors have performed on Boston Common, illustrating for the community-at-large, in an environment where she is the one "in place," the challenges faced by those living on the streets: "As the Heat Rises," about a night spent on a heating grate; "Don't Let Them Take My Cart Away," on the fear of robbery and assault; and "Understanding the Territorial Imperative," or how to find a place to sleep that isn't already taken.

But perhaps even more significantly, the recently formed HEAT (Homeless Emergency Action Taskforce), composed of homeless individuals and other homeless advocates, has complied a number of groups' writings as testimony to the conditions facing Boston's homeless population, and utilized them in lobby efforts to highlight pressing social justice issues using the voices of the homeless themselves. First-hand experiences with the ways in which toxic environments, dumping, unsafe sites, violence, and overcrowding all disproportionately affect the city's homeless underclass are finding their way into mainstream politics of place, through mailings, leaflets, and readings in increasingly public forums. And while still existing very much on the margins of the life of the city, each story validates experience, reanimates the past, helps to 
create relationships and communities in the midst of isolation and degradation, and retrieves a bit of a life from the landscape of invisibility.

\section{Works Cited}

Barthes, Roland. Camera Lucida: Reflections on Photography. New York: Hill and Wang, 1981.

Berger, John. Another Way of Telling. New York: Vintage International, 1982.

Berry, Wendell. What are People For? San Francisco: North Point Press, 1990.

Chalfen, Richard. "A Sociovidistic Approach to Children's Filmmaking: The Philadelphia Project" Studies in Visual Communication 7 (1): 2-33, 1981.

Ewald, Wendy. Portraits and Dreams: Photographs and Stories by Children of the Appalachias. New York: Writers and Readers Publications, Inc, 1975.

-------. Retratos y Suenos/Portraits and Dreams: Photo-graphs by Mexican Children. Exhibition Catalogue, 1993.

Gauntlett, David. Video Critical: Children, the Environment, and Media Power. London: John Libbey Media, 1997.

Hubbard, Jim. Shooting Back: A Photographic View of Life by Homeless Children. San Francisco: Chronicle Books, 1991.

Jackson, John Brinckerhoff. "The Westward Moving House". Ervin H. Zube, ed. Landscapes, vol. 2: 8-21, 1953.

Passaro, Joanne. The Unequal Homeless. New York: Routledge, 1996.

Rossi, Peter. Down and Out in America. Chicago: University of Chicago Press, 1989.

Stringer, Lee. Grand Central Winter. New York: Washington Square Press, 1998.

United States Council of Mayors. Hunger and Homelessness Survey: A Status Report on Hunger and Homelessness in America's Cities. Washington D.C.: City Policy Associates, 2011.

Vanderstaay, Steven. Street Lives. Philadelphia: New Society Publishers, 1992.

Wang, Carolyn and Mary Ann Burris. "Empowerment Through Photovoice: Portraits of Participation." Health Education Quarterly 21(2):171-186, 1994.

Worth, Sol and John Adair. Through Navajo Eyes: An Exploration in Film Communication and Anthropology. Albuquerque, NM: University of New Mexico Press, 1997. 